Várnay Ernö

\title{
Az Európai Unió Bírósága visszautal a magyar bírósághoz
}

\section{Deference from the European Court of Justice to the Hungarian Courts}

\begin{abstract}
Az Európai Bíróság elözetes döntéshozatali eljárások során hozott határozatai jelentős számban tartalmaznak visszautalást az előterjesztô bírósághoz, amelyek az uniós jogi kérdés megitéléséhez szükséges ténybeli, illetve jogi környezet további vizsgálatát teszik a bíróság feladatává. A jelen írás annak a kutatásnak a kezdeti stádiumát villantja fel néhány eset ismertetésén keresztül, amelynek célja a visszautalások utóéletének teljeskörü feltárása.
\end{abstract}

Kulcsszavak: Európai Bíróság, előzetes döntéshozatal, visszautalás, ténybeli és/vagy jogi környezet feltárása, előterjesztő magyar bíróság

In the decisions of the European Court of Justice delivered in preliminary ruling procedures one can relatively often find deferences to the referring national courts rendering their task the further exploration and evaluation of the factual and/or legal background of the case. The present paper gives - by presenting some court cases - a first insight in a research in its preliminary phase the objective of which is to examine the afterlife of all the deferences to the Hungarian courts.

Keywords: European Court of Justice, preliminary ruling procedure, deference to the referring national courts, further examination of the factual and/ or legal circumstances of the case as task of the Hungarian courts

\section{Bevezetés}

Az alábbi írásban egy korai stádiumban lévő kutatás kezdeti fejleményeiből szeretnék ízelítőt adni, tehát a szöveg nem a szó valódi értelmében vett kutatási eredményekről szóló beszámolót tartalmaz.

Várnay Ernő tudományos tanácsadó, MTA Társadalomtudományi Kutató Központ Jogtudományi Intézet, egyetemi tanár, Debreceni Egyetem, Állam- és Jogtudományi Kar 
A kutatás a magyar bíróságok által az Európai Unió Bíróságához előzetes döntéshozatalra tett előterjesztések egy eddig, mondhatni, alig kutatott aspektusához kapcsolódik: a Bíróság előzetes döntése „utóéletének” szisztematikus feltárását túzte célul. A kutatás egyik ígéretes területe az a jelenség, amikor az Európai Bíróság határozatában (ítélet, végzés) bizonyos kérdések tekintetében a nemzeti bíróságra testál feladatokat, mintegy „visszautalva” az előterjesztő bírósághoz.

A jelenség először az Európai Bíróság passzivizmusának kutatása során került elém. Daniel Sarmiento nyomán (Sarmiento, 2012:27-28) azt is az Európai Bíróság paszszivizmusa (nála „minimalizmusként” szerepel) megnyilvánulásának tekintem, amikor a Bíróság a nemzeti bíróság által feltett kérdést nem vagy nem teljesen válaszolja meg, illetve bizonyos kérdések megválaszolása tekintetében a tagállami bíróságot jelöli meg hatáskörrel rendelkező bíróságként, vagy másképpen a tagállami bíróság feladatává teszi a felmerült kérdés megválaszolását, illetve megítélését.

Átvizsgálva a Bíróság 2008-2018 között nagytanácsban hozott határozatait azt találtam, hogy a 2008 és 2016 között az előzetes döntéshozatali eljárásban hozott döntések 33-40\%-ában, míg a 2017-2018-as időszakban a döntések 37,5\%-ában olvasható valamilyen visszautalás. ${ }^{1}$

\section{Visszautalás a magyar bíróságokhoz}

A magyar bíróságoktól érkezett előterjesztések nyomán hozott határozatok fenti szempontú vizsgálatába az Európai Bíróság 109 határozatát vontam be. (A Bíróság honlapján található kereső ennyi határozatot [befejezett ügyet] jelzett.)

Ezek közül 39-ben találtam nyomát annak, hogy a Bíróság valamely kérdés eldöntését kifejezetten a nemzeti bíróság hatáskörébe utalja (vissza), illetve feladatává minősíti (36\%). Ez az arány nagyon közel van a nagytanácsban hozott határozatok esetében adódóhoz. Azt tehát minden különösebb kockázat nélkül kimondhatjuk, hogy nem elhanyagolható jelenségről van szó. Sajnos mostanáig a 39 ügyből csak 11 esetében sikerült a magyar bíróságoknak az előzetes döntést követő határozataihoz hozzáférni.

A 39 határozat már „első olvasatra” is kínált tipizálási lehetőséget. Megállapítható, hogy a visszautalásoknak a tagállami bíróság feladata (hatásköre) szempontjából két válfaja van. Az egyik, amikor a Bíróság az úgynevezett alapeljárásban (a magyar bíróság előtt folyó eljárás) felmerült kérdések megválaszolása érdekében tények vizsgálatát tartja szükségesnek, a másik, amikor a tagállami jogi környezet további feltárását, illetve az uniós jog szempontjából vett értékelését tartja szükségesnek. Az alábbiakban a két típusú visszautalásra hozok példákat, illetve bemutatom, hogy a magyar bíróságok hogyan teljesítették a rájuk testált feladatot.

Sajnos mostanáig nem sikerült meggyőzően alátámasztani, hogy itt a bírói passzivizmus egyértelmủ megnyilvánulásáról van szó. (Várnay, 2019) 


\section{Az Európai Bíróság tények feltárását, tények jogi értékelését utalja vissza}

\section{A Hervis-ügy}

A Hervis Sport- és Divatkereskedelmi Kft. a Székesfehérvári Törvényszéken benyújtott keresetében arra hivatkozva kérte a Nemzeti Adó- és Vámhivatal Közép-Dunántúli Regionális Adó Fơigazgatósága határozatának felülvizsgálatát, hogy a határozat jogalapjául szolgáló egyes ágazatokat terhelő különadóról szóló 2010. évi XCIV. törvényre vonatkozó rendelkezései sértik az EUMSZ 18., 49-55., 65. és 110. cikkeit.

A törvény értelmében a bolti kiskereskedelmet folytató kapcsolt vállalkozásoknak a csoporthoz tartozó valamennyi vállalkozás által - a Magyarországon elért teljes árbevételük alapján - kell megfizetniük a fizetendő különadó egy részét.

A Székesfehérvári Törvényszék előzetes döntés iránt előterjesztést tett, amelyben a törvényhelyeknek a keresetben is felhozott rendelkezéseivel való összeegyeztethetőségére kérdezett. ${ }^{2}$

A Bíróság úgy találta, hogy a törvény az EUMSZ 49. cikkében rögzített letelepedés szabadságával összefüggésben vizsgálandó.

A Bíróság megállapította: ${ }^{3}$

„Meg kell említeni, hogy olyan adójogi jogszabály vonatkozásában, amelyröl az alapügyben is szó van, és amelynek tárgya az árbevétel adóztatása, a vállalatcsoportba tartozó adóalany helyzete összehasonlítható az olyan adóalany helyzetével, amely nem tartozik e csoporthoz. Pontosabban mind az érintett tagállam bolti kiskereskedelmi piacán tevékenykedö és vállalatcsoportba tartozó jogi személyek, mind pedig azok, amelyek nem tartoznak ilyen csoporthoz, a különadó alanyai, és árbevételük független a többi adóalanyétól.

E feltételek mellett, amennyiben bizonyitott, hogy az érintett tagállam bolti kiskereskedelmi piacán a vállalatcsoportba tartozó és a különadó legfelsô adósávjába eső adóalanyok többnyire más tagállamban székhellyel rendelkezö társaságoknak - a nemzeti jogszabály értelmében - kapcsolt vállalkozásai, a különadó erösen progressziv adómértékének az összevont árbevételből álló adóalapra történő alkalmazása különösen azzal a veszéllyel jár, hogy hátrányosan érinti a más tagállamban székhellyel rendelkező társaságok kapcsolt vállalkozásait.

A kérdést előterjesztő bíróság feladata annak vizsgálata, hogy - figyelembe véve azon általános körülményeket, amelyek között a nemzeti jogszabály kifejti hatását - ez a feltétel teljesül-e."

A magyar bíróságnak tehát fel kellett tárnia, hogy az adott adójogszabály alá tartozó adóalanyok más tagállamban székhellyel rendelkező társaságok kapcsolt vállalkozásai-e. Ha ezen tények pótlólagos vizsgálata pozitív eredményre vezet, úgy megállapítandó lesz az adótörvény rendelkezéseinek közvetett diszkriminációt megvalósító volta, amely beleütközik az EUMSZ 49. cikkében foglalt, a letelepedés (vállalkozás) szabadságának korlátozását tiltó szabályába. Innét az következik, hogy a nemzeti bíróságnak

C-385/12. sz., Hervis Sport és Divatkereskedelmi Kft.-ügy [ECLI:EU:C:2014:47].

Lásd az ítélet 38-40. pontjait.

Európai Tükör 2019/3. 
az uniós joggal ütköző nemzeti jogot félre kell tenni, az nem alkalmazható, illetve az ilyen jogszabályon alapuló hatósági határozat jogsértőnek minősül.

A Székesfehérvári Közigazgatási és Munkaügyi Bíróság a felperes által rendelkezésére bocsátott iratok alapján megállapította, hogy öt adóalany volt érintve a sérelmezett nemzeti szabályozással. A per folyamán bizonyítást nyert továbbá, hogy az említett öt adóalany mindegyike az Európai Unió más tagállamában honos vállalkozás többségi befolyása alatt múködött a 2010. évben. ${ }^{4} \mathrm{~A}$ bíróság a másodfokú adóhatóság határozatát hatályon kívül helyezte, és az elsőfokú adóhatóságot új eljárásra kötelezte.

\section{A Schenker-ügy}

Az alapeljárás a Schenker Nemzetközi Szállítmányozási és Logisztikai Kft. (felperes) és a Nemzeti Adó-és Vámhivatal Fellebbviteli Igazgatósága (NAV, alperes) között a Debreceni Közigazgatási és Munkaügyi Bíróságon zajlott.

Tekintettel arra, hogy a tényállásra az Európai Unió közvetlenül alkalmazandó vámjogát és jövedéki jogát kellett alkalmazni, a per tárgyát képező NAV határozat jogszerűségének megítélése érdekében a debreceni bíróság előzetes döntést kért az Európai Bíróságtól.

A Bíróság ítéletében ${ }^{5}$ többek között kimondta:

„Az alapügyben szóban forgó helyzetben az árut a Kombinált Nómenklatúra (KN) helyes árucsoportjába, azonban a KN helytelen vámtarifa alszáma alá sorolták be.

[A 2016. október 6-i végzéssel kijavítva] Emlékeztetni kell arra, hogy a 444/2002 rendelettel módosított 2454/93 rendelet 859. cikke jogszerüen alakít ki olyan szabályozást, amely kimerítően szabályozza azon, a Vámkódex 204. cikke értelmében vett mulasztásokat, amelyek „nincsenek jelentős hatással a szóban forgó átmeneti megörzés vagy vámeljárás helyes lefolytatására." ${ }^{6}$

„[A 2016. október 6-i végzéssel kijavítva] E tekintetben hangsúlyozni kell, hogy a 444/2002 rendelettel módosított 2454/93 rendelet 859. cikke lehetövé teszi, hogy ne tekintsék az árutovábbitási eljárás lefolytatására nézve jelentős hatásúnak az emlitett eljárás alkalmazásából adódó kötelezettségek valamelyikének elmulasztását, amennyiben az e cikk 2. pontjában felsorolt három feltétel, és az említett cikk első albekezdésében felsorolt három feltétel teljesül.

A kérdést előterjesztő bíróság feladata megvizsgálni, hogy e feltételek összessége teljesül-e az alapeljárással kapcsolatban.

Igenlő válasz esetén az áru besorolása során vétett hiba tehát úgy tekinthetô, mint amelynek nincs jelentôs hatása az egymást követő vámeljárások lefolytatására."

A debreceni bíróság az Európai Bíróság által megjelölt uniós jogszabályhelyek feltételrendszerét beemelte vizsgálódása körébe, majd megállapította:

„A biróság álláspontja szerint a rendelkezésre álló adatokból megállapítható, hogy a felperes nem szándékozott és nem tett arra kísérletet, hogy az árut jogellenesen kivonja

Székesfehérvári Közigazgatási és Munkaügyi Bíróság K.27060/2014/24.

C-409/14. sz.Schenker-ügy [ECLI:EU:C:2016:643], az ítélet 114-118. pontja.

2012. szeptember 6-i Eurogate Distribution-ítélet, C28/11, EU:C:2012:533, 34. pont

Európai Tükör 2019/3. 
a vámfelügyelet alól, nem mutatott súlyos gondatlanságot a felperes magatartása, és az áru helyzetének rendezéséhez szükséges alakiság a vámtarifaszám helyes meghatározásával teljesülhet. Megállapitható ugyanis, hogy a kérdéses árukat sértetlen állapotban mutatták be a rendeltetési vámhivatalnak és a Vhr. 356. cikk szerinti okmány a vámhivatalnak be is lett mutatva az ellenörzéskor."

$\mathrm{Az}$ ítélet idézett szövegéből kiolvasható, hogy a nemzeti bíróság a rendelkezésére álló tényeket (történt-e legalább kísérlet a kérdéses áru kivonására a vámfelügyelet alól, sértetlen állapotban mutatták-e be az árut) vizsgálta meg és értékelte immár az Európai Bíróság által meghatározott feladata végrehajtásaként.

A Debreceni Közigazgatási és Munkaügyi Bíróság - az Európai Bíróság ítéletben foglalt értelmezéseket más vonatkozásban is hivatkozva - a NAV határozatot az elsőfokú határozatra is kiterjedő hatállyal hatályon kívül helyezte.

\section{A Berlington-ügy}

Az alapeljárás a Fővárosi Törvényszéken folyt a Berlington Hungary Tanácsadó és Szolgáltató Kft. és társainak a magyar állammal szemben indított kártérítési perében.

A jogalkotó 2011. november 1-jei törvénye megötszörözte a játéktermekben felállított pénznyerő automaták üzemeltetését terhelő havi tételes játékadó mértékét, majd egy 2012. október 9-én kihirdetett törvény 2012. október 10-i hatállyal megtiltotta a pénznyerő automaták kaszinókon kívüli üzemeltetését, a pénznyerő automaták üzemeltetésére vonatkozó engedélyek pedig a törvény erejénél fogva érvényességüket veszítették.

A felperesek azt állították, hogy az adóemelés, illetve a tiltás kárt okozott. A kárt a magyar állam uniós jogot sértő jogalkotása okozta.

A Fôvárosi Törvényszék az uniós jog megsértésének, illetve a magyar állam mint uniós tagállam kártérítési felelősségének fennálltára vonatkozó kérdésekkel előzetes döntést kért az Európai Bíróságtól. ${ }^{8}$

Az Európai Bíróság ítéletének 40. pontjában kimondta:

„E tekintetben meg kell állapítani, hogy amennyiben a 2011. évi módosító törvény ténylegesen akadályozza, zavarja vagy kevésbé vonzóvá teszi a pénznyerő automaták magyarországi játéktermekben való üzemeltetésében álló szolgáltatás szabad nyújtását, aminek vizsgálata a nemzeti bíróság feladata, azt a szolgáltatásnyújtás EUMSZ 56. cikkben biztositott szabadsága korlátozásának kell tekinteni."

Ezt a pontot azonban együtt kell olvasnunk az ítélet indoklásának 41. pontjában írtakkal:

„Ez lenne a helyzet, ha a kérdést előterjesztő bíróság megállapitaná, hogy a 2011. évi módositó törvényben előirt adóemelés azzal a hatással jár, hogy a pénznyerö automaták üzemeltetésére irányuló tevékenység a kaszinókra korlátozódik, amelyekre ezen adóemelés nem vonatkozott. Így az emlitett adóemelés a pénznyerő automaták kaszinókon kivüli üzemeltetésének

Debreceni Közigazgatási és Munkaügyi Bíróság14. K.27.522/2016/11.

C-98/14. sz. Berlington Hungary és társai-ügy [ECLI:EU:C:2015:386].

Európai Tükör 2019/3. 
tilalma által gyakorolttal összehasonlitható hatást fejtene ki, amit az állandó itélkezési gyakorlat a szolgáltatásnyújtás szabadsága korlátozásának tekint."

A Fővárosi Törvényszéknek (és tegyük hozzá: az ítéletét fellebbezés folytán elbíráló Fővárosi Ítélőtáblának, majd a felülvizsgálati kérelmet elbíráló Kúriának) tehát a jogsértés fennállásának tisztázása érdekében tényeket kellett feltárnia (nevezetesen, hogy a drasztikus adóemelés ténylegesen akadályozta, zavarta vagy kevésbé vonzóvá tette-e a pénznyerő automaták játéktermekben való üzemeltetését).

A Fővárosi Törvényszék az uniós jog (Francovich-felelősség) alapján fennálló tagállami kárfelelősség feltételeinek körében megvizsgálta az adóemelés hatását a pénznyerő automaták múködtetésére. A bíróság az Európai Bíróság ítéletének 41. pontjában foglaltakat úgy értelmezte, hogy az „akadályozás, zavarás, illetve kevésbé vonzóvá tétel” akkor állapítható meg, ha a tények azt támasztják alá, hogy az adóemelés a tevékenység tiltásának megfelelő hatást váltott ki.

A bíróság megkereste a Nemzeti Adó-és Vámhivatalt a szükséges tényadatok megszerzése végett. A NAV válaszának adatai alapján megállapította, hogy a pénznyerő automaták száma a játéktermekben jelentősen csökkent, ugyanakkor nem állítható, hogy a pénznyerő automaták üzemeltetése megszűnt volna. A Fővárosi Törvényszék utalva a Bíróság ítéletének 41. pontjában foglaltakra (bár helytelenül a 40. pontot jelölte meg) - megállapította, hogy nem lehetett megalapozottan arra következtetni, hogy az adóemelés akadályozta, zavarta, korlátozta a szerencsejáték-szolgáltatás nyújtását.

$\mathrm{Az}$ ítélet elleni fellebbezést elbíráló Fővárosi Ítélőtábla hasonlóan érvelt, és ítéletében rögzítette: az EUB ítélete szerint, hogyha a törvény egyedüli hatása csak az, hogy költségesebbé teszi a tevékenységet, akkor az nem tartozik a szolgáltatásnyújtás szabadságának korlátozását jelentő körbe, vagyis az adóemeléssel összefüggésben nem lehet megállapítani az EUMSZ 56. cikkének sérelmét. A peradatokból csak ilyen hatásra lehet következtetni, azt azonban, hogy a felperesi tevékenység az adóemelés hatására ellehetetlenült volna, a rendelkezésre álló adatok nem támasztják alá. ${ }^{10}$

A jogerős ítélettel szemben benyújtott felülvizsgálati kérelmet elbírálva a Kúria rész- és közbenső ítéletében megerősítette ezt az érvelést. ${ }^{11}$

Lásd különösen: Anomar és társai ítélet, C6/01, EU:C:2003:446, 75. pont; Bizottság kontra Görögország ítélet, C65/05, EU:C:2006:673, 53. pont.

10 Fővárosi Ítélőtábla 5.Pf.21.081/2016/6/II. A Fővárosi Törvényszék ítéletét ezen ítélet alapján ismertettük.

11 Kúria Pfv.IV.20.211/2017/13 [47 pont]. 


\section{A Bíróság a tagállami jog, a tagállami jogi környezet további vizsgálatát, az uniós jog fényében történö értékelését tartja szükségesnek}

\section{Az Almos-ügy}

Az alapeljárás az Almos Agrárkülkereskedelmi Kft. (felperes) és a Nemzeti Adó és Vámhivatal Középmagyarországi Regionális Adó Főigazgatósága (NAV, alperes) között a Kúria előtt zajlott.

A felülvizsgálati kérelem az EU hozzáadottérték-adó szabályozása (héairányelv) alá eső áfatörvény alapján született, és a felperes adóalap-csökkentésen alapuló visszaigénylési kérelmét elutasító NAV határozatát támadta.

A vita abból adódott, hogy a magyar áfatörvény adóalap-csökkentésre vonatkozó előírásai nem tartalmazták a tényállásban szereplő esetet, amikor is az eladó azért nem kapja meg az értékesítés ellenértékét, mert az adásvételi szerződést felbontották (elállásra került sor), az áru a tulajdonában maradt.

A Kúria előzetes döntést kért az Európai Bíróságtól egyebek között az alábbi kérdések megválaszolását kérve:

„1. A 2010. december 31-ig hatályos [áfatörvény] 77. §[ának] (1) és (2) bekezdései összeegyeztethető szabályozást tartalmaznak-e a [héairányelv] 90. cikk[ének] (1) bekezdésében szabályozottakkal, vagyis a[z áfatörvény] tartalmazza-e valamennyi ott felsorolt adóalapot csökkentő esetet?"

„5. Értelmezhető-e a [héairányelv] 90. cikk[ének] (2) bekezdése akként, hogy a tagállamoknak lehetőségük van a teljes vagy részleges nemfizetés esetén az adóalap csökkentésétől eltekinteni, ha igen, erről kifejezetten a tagállami jogszabálynak tiltó formában kell rendelkeznie, vagy [a] szabályozás hiánya ugyanilyen joghatást vált ki?"

A Bíróság ítéletében ${ }^{12}$ ezeket a kérdéseket így válaszolta meg:

„[A]z elsô és az ötödik kérdésre azt a választ kell adni, hogy a héairányelv 90. cikkének rendelkezéseit úgy kell értelmezni, hogy azokkal nem ellentétes az olyan nemzeti rendelkezés, amely nem írja elö a héaalap csökkentését az ár meg nem fizetése esetében, amennyiben az $e$ cikk (2) bekezdésében előirt eltérés kerül alkalmazásra. Mindazonáltal e rendelkezésnek ki kell terjednie minden más olyan esetre, amikor az emlitett cikk (1) bekezdése szerint az ügylet teljesítését követően az adóalany az ellenértéket részben vagy egészben nem kapja meg, aminek vizsgálata a nemzeti bíróság feladata."

$\mathrm{Az}$ előterjesztő magyar bíróság tehát azt a feladatot kapta, hogy vizsgálja meg az áfatörvény rendszerét, és foglaljon állást arról, hogy az ad-e lehetőséget a tényállás szerinti esetben - amelyre az uniós irányelv vonatkozik - az adóalap csökkentésére. Lássuk be, a feladat nem volt túl nehéz.

A Kúria ítéletében ${ }^{13}$ így fogalmazott:

„A Bíróság ítéletének 28. pontjában írt feladat kapcsán a Kúria kifejti, hogy a nemzeti jogalkotó ugyan szabad mérlegelési és döntési jogosultsággal rendelkezik az Irányelv nemzeti jogba

C-337/13. sz. Almos Agrárkülkereskedelmi Kft.-ügy [ECLI:EU:C:2014:328], az ítélet 11. pontja. Kúria Kfv.III.35.483/2014/5. 
való nyelvi megjelenitése vonatkozásában, azonban mozgástere nem korlátlan. Az átültetett jogi normának messzemenően meg kell felelnie az Irányelvben foglalt céloknak.

A Bíróság itéletének 22.) és 25.) pontja összevetéséböl az a következtetés vonható le, hogy amennyiben a vételár (a szolgáltatás dija) teljes vagy részleges meg nem fizetésére azért került sor, mert a felek közötti jogviszony megszünése folytán az eladó (lízingbeadó) a vételár (lízingdij) megfizetését már nem követelheti, az adóalap csökkentésére való jogosultság fennáll."

A Kúria a felperes kérelmének helyt adó jogerős ítéletet hatályában fenntartotta.

\section{A Dél-Zempléni Nektár Leader Nonprofit Kft.-ügy}

$\mathrm{Az}$ alapeljárás a Dél-Zempléni Nektár Leader (DZNLN) Nonprofit Kft. (felperes) és a vidékfejlesztési miniszter (alperes) között zajlott.

A DZNLN-t, a magyar jog alapján létrejött nonprofit korlátolt felelősségú társaságot az Új Magyarország Vidékfejlesztési Program Irányító Hatósága 2008. szeptember 26-i határozatával helyi Leader-akciócsoportként ismerte el.

A DZNLN a továbbiakban tevékenységét helyi Leader-akciócsoportként mind az uniós jog, mind a nemzeti jog előírásainak betartásával folytatta.

$\mathrm{Az}$ említett hatóság 2012. április 26-i határozatával a DZNLN helyi Leaderakciócsoportként való elismerését 2012. április 30-i hatállyal visszavonta azon indokkal, hogy az 54/2011. (VI. 10.) VM rendelet 2. §-ának (1)-(3) bekezdése értelmében ezen időponttól a helyi Leader-akciócsoport címmel kizárólag egyesület rendelkezhet, kizárva így többek között a DZNLN-hez hasonlóan nonprofit kft.-ként múködő jogalanyokat.

A jogvita tárgya a Leader-akciócsoport DZNLN helyi akciócsoportként való elismerésének visszavonására vonatkozó határozata jogszerüsége volt. A Fővárosi Közigazgatási és Munkaügyi Bíróság terjesztett elő előzetes döntés iránti kérelmet.

A kérdések között szerepeltek a következők:

Értelmezhetők-e úgy a fenti rendeletek, hogy az adott tagállamnak mérlegelési jogkörébe tartozik azon döntés, hogy a[z 1698/2005 rendelet] 62. cikk[ének] (1) bekezdésében megfogalmazott feltételeknek megfelelően működő helyi akciócsoportot, amely egyébként működése során mindvégig megfelelt az összes vonatkozó tagállami és közösségi jogszabálynak, a feltételektől függetlenül megszűntté nyilvánítson, és csak egy új szervezeti formában múködő helyi akciócsoport részére tegye lehetővé a működést?

Értelmezhetők-e úgy a fenti rendeletek, hogy az adott tagállam a már folyamatban lévő támogatási programok, illetve programozási időszak alatt is megváltoztathatja adott esetben a helyi akciócsoportok múködési jogi kereteit?

Hogyan kell értelmezni a fenti rendeleteket abban az esetben, ha a korábban eredményesen és jogszerűen múködő helyi akciócsoport megszűnik? A helyi akciócsoport által vállalt kötelezettségeknek és szerzett jogoknak mi lesz ebben az esetben a [sorsuk], különös tekintettel a visszavonással érintett teljes személyi körre?

A Bíróság végzésének ${ }^{14}$ indoklásában hivatalból felvetette az Európai Unió Alapjogi Chartájában foglalt elvek tagállamok általi betartásának kötelezettségét:

14 C-24/13. sz. DélZempléni Nektár Leader Nonprofit Kft.-ügy [ECLI:EU:C:2014:40]. 
„Másodszor emlékeztetni kell arra, hogy az Európai Unió Alapjogi Chartája (a továbbiakban: Charta) 51. cikkének (1) bekezdése értelmében a tagállamok annyiban a Charta rendelkezéseinek címzettjei, amennyiben az Unió jogát hajtják végre. E végrehajtás során a tagállamok továbbá kötelesek biztosítani e jog általános jogelveinek - így különösen az egyenlő bánásmód, a jogbiztonság, a bizalomvédelem és az arányosság elvének - betartását." 15

A végzés rendelkező részében pedig leszögezte:

„1) Az Európai Mezőgazdasági Vidékfejlesztési Alapból (EMVA) nyújtandó vidékfejlesztési támogatásról szóló, 2005. szeptember 20i 1698/2005/EK tanácsi rendelet rendelkezéseit, és különösen e rendelet 61. és 62. cikkét úgy kell értelmezni, hogy azok nem követelik meg, illetve föszabály szerint nem tiltják meg az azt előíró nemzeti rendelkezések elfogadását, hogy az olyan helyi akciócsoport, amely megfelel az ezen rendelet 62. cikke (1) bekezdésében felsoroltösszes feltételnek, kizárólag egy meghatározott jogi formában müködjön. Mindazonáltal a kérdést elöterjesztő bíróság feladata, hogy megbizonyosodjon arról, hogy a releváns jellemzők összességére figyelemmel az ilyen szabályozás nem akadályozza a hivatkozott rendelet közvetlen alkalmazását, és a rendelet rendelkezéseinek keretei között maradva pontosítja a rendelet által a tagállamok számára biztositott mérlegelési mozgástér gyakorlását. Továbbá e bíróság feladata megbizonyosodni arról, hogy a nemzeti szabályozás tiszteletben tartja az Európai Unió Alapjogi Chartájának rendelkezéseit és az Unió általános jogelveit.

2) Az uniós joggal föszabály szerint nem ellentétes az, hogy egy egyéves átmeneti idôszak lejártával az azt előíró nemzeti szabályozás legyen alkalmazandó az olyan helyi akciócsoportokra is, amelyeket a korábbi nemzeti szabályozás értelmében jogszerüen más jogi formában hoztak létre, hogy a helyi akciócsoportok kizárólag meghatározott jogi formában müködhetnek, miközben a támogatási programok, illetve az ezzel kapcsolatos programozási időszak már folyamatban vannak. Ez a helyzet azonban csak akkor áll fenn, ha - különös figyelemmel az egymást követő nemzeti szabályozások sajátos jellemzőire, és azok konkrét következményeire - az új szabályozás ilyen helyi akciócsoportokra való alkalmazása az 1698/2005 rendelet rendelkezéseinek keretei között maradva pontosítja az e rendelet által a tagállamok részére biztositott mérlegelési mozgástér gyakorlását, illetve ez az Európai Unió Alapjogi Chartája rendelkezéseinek és az Unió általános jogelveinek tiszteletben tartásával történik, aminek megvizsgálása a kérdést elöterjesztő bíróság feladata."

Az előterjesztő bíróság a vitatott határozatot hatályon kívül helyezte, és a közigazgatási szervet új eljárás lefolytatására kötelezte. Az Európai Bíróság által adott feladatot nem végezhette el, hiszen az már a bíróság reformatórius jogkörét igényelte volna. (Varju-Kovács, 2015) Így arra szorítkozott, hogy a Bíróság ítéletében foglalt követelményeket iránymutatásként rögzítette:

„A megismételt eljárásban az alperes (közigazgatási szerv) a minösítés visszavonása körében minden körülményt és következményt teljes körüen értékelve, az Európai Unió általános és speciális céljaival, és jogszabályaival együttesen értékelve kell meghoznia, azt teljes körüen indokolnia."

C-24/13. sz. DélZempléni Nektár Leader Nonprofit Kft.-ügy [ECLI:EU:C:2014:40], az ítélet 17. pontja. Lásd különösen a C313/99. sz., Mulligan és társai 2002. június 20-án ügyben hozott ítélet [EBHT 2002., I-5719. o.] 46. pontját, valamint a C-241/07. sz. JK OtsaTalu-ügyben 2009. június 4én hozott ítélet [EBHT 2009., I-4323. o.] 46. pontját. 
Az alperes közigazgatási szerv a megismételt eljárásban a 54/2011. (VI. 10.) VM rendelet 2. § (1)-(3) bekezdése alapján a Leader Helyi Akciócsoport címet visszavonta. A felperes ezzel a határozattal szemben is kereseti kérelmet terjesztett elö.

A Kaposvári Közigazgatási és Munkaügyi Bíróság ítéletével az alperes határozatát hatályon kívül helyezte, és az alperest új eljárás lefolytatására kötelezte. Rögzítette, hogy „az alperes megsértette a közigazgatási hatósági eljárási szolgáltatás általános szabályairól szóló 2004. évi CXL. tv 109.§ (4) bekezdésében írt rendelkezést, merta határozata a megismételt eljárásra adott iránymutatásról nem rendelkezett".

A második megismételt eljárásban az alperes (közigazgatási szerv) ismét a visszavonásról határozott, indoklásában azonban a korábbiakhoz képest kibővített tartalmú határozatot hozott.

A felperes ennek a határozatnak a hatályon kívül helyezése érdekében is pert indított.

A Kaposvári Közigazgatási és Munkaügyi Bíróság a határozatot hatályon kívül helyezte és az alperest új eljárás lefolytatására kötelezte. ${ }^{16}$ Indoklásában kitért arra, hogy az alperes határozatában az Európai Unió általános céljai közül kizárólag a jogbiztonság elvének érvényesülésével összefüggésben tartalmazott részletesebb értékelést, illetve indoklást.

Ezzel szemben azonban az alperes az Európai Unió további általános és a területre vonatkozó speciális céljait egyáltalán nem jelenítette meg a határozatában, mint ahogy arra sem tért ki, hogy milyen következményei vannak, illetve lehetnek annak, hogy a felperes LEADER HACS címének visszavonásáról rendelkezett az alperesi hatóság.

„A megismételt eljárásban az alperesnek a Fővárosi Közigazgatási és Munkaügyi Bíróság 23.K.32.0../201./10. szám alatti itéletében foglaltaknak megfelelöen az Európai Bíróság C-24/13. számúvégzésében foglalt körülményeket, tényeket, következményeket kell vizsgálnia és ennek alapján kell minden körülményt és következményt összességében komplex módon az Európai Unió általános és speciális céljaival és jogszabályaival együttesen értékelve a döntését meghoznia. A határozatban az alperesnek a következményekkel összefüggésben ki kell fejtenie az álláspontját és az erre vonatkozó indokolását, valamint az Európai Unió általános és speciális céljait, azok megvalósulását is értékelnie kell."

Észre kell vennünk, hogy a magyar jogrend nem teszi lehetővé, hogy a közigazgatási bíróság minden esetben eleget tudjon tenni az Európai Bíróság által meghatározott követelményeknek. Ilyen esetben az iránymutatás ad lehetőséget az Európai Bíróság által adott feladat továbbadására.

A Dél-Zempléni Nektár-ügy kapcsán nem hallgathatjuk el, hogy a Bíróság - és nyomában a magyar bíróság - rendkívül sokrétủ, egyben elmosódó körvonalú feladatot testált a magyar bíróságra, illetve annak közvetítésével a közigazgatási szervre.

16 Kaposvári Közigazgatási és Munkaügyi Bíróság 1.K.27.448/2016/6/I. szám. Az eset - ideértve a korábbi bírósági határozatokra történő kitételeket - ismertetése ennek az ítéletnek a szövegén alapul. 


\section{Elözetes konklúziók}

Magától értetődik, hogy a kutatás jelen állása mellett nem fogalmazhatók meg végleges állítások. A néhány bemutatott eset alapján a következő megjegyzéseket tesszük.

A visszautalások rámutatnak, hogy az Európai Bíróság a tagállami bíróságok kérdéseire nem mindig tud (akar?) teljes körű választ adni, az uniós jog megfelelő alkalmazása az előterjesztő bíró további aktivitását - ténybeli és jogi környezet további feltárása, értékelése - igényli.

Ez azonban távolról sem jelent mechanikus tevékenységet, szerepet kaphatnak a felek, illetve a bíróság(ok) önálló értelmezései. Az Európai Bíróság adott esetben a magyar bíróságra olyan feladatot ró, amelyet az a magyar jogrendszerben nem tud teljesíteni.

A visszautalások kapcsán (is) egyértelműnek tűnik, hogy az európai jog kánonjában az Európai Bíróság előzetes döntéseinek jogi természete, joghatásai kapcsán rögzült tétel, miszerint az előzetes döntés kötelező az előterjesztő bíróságra, illetve az ügyben eljáró további bíróságokra (Blutman, 2003:395-424), nem elégséges az uniós jognak a tagállami jogrendszerekben történő érvényesülése valóságának megragadására.

\section{Felhasznált irodalom}

Blutman, László (2003): EU-jog a tárgyalóteremben. Az előzetes döntéshozatal. Budapest, KJK Kerszöv.

SARmiento, Daniel (2012): Half a Caseat a Time: Dealing with Judicial Minimalism at the European Court of Justice. In Claes, Monica - DE Visser, Maartje - Popelier, Patricia - VAn DE Heyning, Cathrineeds: Constitutional Conversations in Europe. Cambridge, Intersentia. 11-42.

VARJU, Márton - KovÁcs, András György (2015): The Impossibility of Being a National and a European Judge at the Same Time: Doctrinal Rifts between Hungarian and EU Administrative Law. In BOBEK, Michal ed.:Central European Judgesunderthe European Influence. Hart Publishing. 197-221.

VÁRnAY, Ernő (2019): Judicial Passivism at the European Court of Justice? Kézirat. Szeged. 
